Original Article

\title{
Apakah Pengetahuan dan Dukungan Suami Memengaruhi Rendahnya Penggunaan Metode Kontrasepsi IUD pada Akseptor KB?
}

\section{Does Knowledge and Husband's Support Affect the Low Use of IUD Contraception Methods in Family Planning Acceptors?}

\author{
Christina Entoh, Zulfitriani, Lisda Widianti Longgupa, Sony Bernike Magdalena \\ Sitorus, Nurfatimah, Kadar Ramadhan* \\ Prodi D-III Kebidanan Poso, Poltekkes Kemenkes Palu, Indonesia
}

(*kadarlaure@gmail.com)

\begin{abstract}
ABSTRAK
Intrauterine device (IUD) merupakan alat kontrasepsi Metode Kontrasepsi jangka Panjang (MKJP) yang memiliki efektifitas tinggi dalam mencegah kehamilan, tetapi penggunaan IUD di wilayah puskesmas Mapane hanya 2,3\% saja. Tujuan penelitian untuk mengidentifikasi faktor yang memengaruhi rendahnya penggunaan kontrasepsi IUD di kelurahan Mapane. Desain penelitian ini adalah cross-sectional. Populasi penelitian ini adalah akseptor KB di Kelurahan Mapane yang berjumlah 336 orang. 77 responden terpilih menggunakan purposive sampling. Variabel dalam penelitian ini adalah penggunaan kontrasepsi IUD, pengetahuan, paritas, dukungan suami, dan informasi tenaga kesehatan. Analisis data dalam penelitian ini adalah analisis univariat dan bivariate menggunakan uji chi square. Hasil penelitian menunjukan bahwa faktor pengetahuan kurang 52,0\%, primipara 35,1\%, suami yang tidak mendukung $49,0 \%$ dan yang tidak mendapat informasi tenaga kesehatan $44,3 \%$. Uji chi-square menunjukan pengetahuan yang baik $(\mathrm{p}=0,003)$, dan dukungan suami $(\mathrm{p}=0,015)$ berhubungan dengan pemilihan kontrasepsi IUD. Kesimpulan rendahnya penggunaan kontrasepsi IUD di Kelurahan Mapane dipengaruhi oleh pengetahuan kurang, dan tidak mendapat dukungan suami.
\end{abstract}

Kata kunci : IUD; Pengetahuan; Dukungan Suami; Informasi

\begin{abstract}
Intrauterine device (IUD) is a long-term contraceptive method (MKJP) which has high effectiveness in preventing pregnancy, but the use of IUD in the Mapane health center area is only $2.3 \%$. The purpose of the study was to identify the factors that influence the low use of IUD contraception in the Mapane village. The design of this research is cross sectional. The population of this study were family planning acceptors in Mapane Village, amounting to 336 people. 77 respondents were selected using purposive sampling. The variables in this study were the use of IUD contraception, knowledge, parity, husband's support, and information on health workers. Data analysis in this study was univariate and bivariate analysis using chi square test. The results showed that the knowledge factor was $52.0 \%$ lacking, primiparous $35.1 \%$, husbands who did not support $49.0 \%$ and those who did not receive information from health workers $44.3 \%$. The chi-square test showed good knowledge ( $p=0.003)$, and husband's support $(p=0.015)$ related to the choice of IUD contraception. The low use of IUD contraception in Mapane Village is influenced by lack of knowledge, and not getting husband's support
\end{abstract}

Keywords : IUD ; Knowledge ; Husband Support ; Information

https://doi.org/10.33860/jik.v15i2.476

(C) 2021 by the authors. Submitted for possible open access publication under the terms and conditions of the Creative

Commons Attribution (CC BY SA) license (https://creativecommons.org/licenses/by-sa/4.0/). 


\section{PENDAHULUAN}

Peningkatan jumlah penduduk menjadi salah satu masalah di setiap negara, termasuk Indonesia. Dampak dari peningkatan jumlah penduduk yaitu tingginya angka kelahiran yang mengakibatkan kurangnya gizi pada anak, sehingga menjadi salah satu faktor terjadinya stunting. Stunting dapat membuat kecerdasan anak dibawah rata- rata dan sistem imun yang kurang, hal ini dapat menyebabkan sumber daya manusia (SDM) yang tidak berkualitas. ${ }^{1}$ Jumlah penduduk Indonesi menurut hasil sensus penduduk tahun 2020 adalah 270,20 juta jiwa dengan rasio jenis kelamin penduduk Indonesia sebesar 102, terdapat 102 laki-laki untuk setiap 100 perempuan. ${ }^{2}$ Jumlah penduduk yang semakin bertambah harus dibarengi dengan meningkatnya jumlah akseptor Keluarga Berencana (KB). ${ }^{3}$.

Tahun 2019, Di antara 1,9 miliar kelompok Wanita Usia Reproduksi (15-49 tahun) di seluruh dunia, 1,1 miliar memiliki kebutuhan keluarga berencana; dari jumlah tersebut, 842 juta menggunakan metode kontrasepsi, dan 270 juta adalah unmet need. , $^{4,5}$ Proporsi kebutuhan KB yang dipenuhi oleh metode modern, indikator Tujuan Pembangunan Berkelanjutan (SDG) 3.7.1, adalah $75,7 \%$ secara global pada tahun 2019, namun kurang dari setengah kebutuhan keluarga berencana terpenuhi di Afrika Tengah dan Barat. $^{4}$ Prevalensi sterilisasi, IUD dan metode tradisional telah menurun di seluruh dunia sejak tahun $1994 .^{6}$

Angka pemakaian kontrasepsi (CPR) semua cara pada Pasangan Usia Subur (PUS) usia 15-49 Tahun yang pernah kawin tahun 2019 di Indonesia adalah 62,54\%, angka ini menurun jika dibanding tahun $2018(64,51 \%)$ dan 2017 (64,49\%). Untuk propinsi Sulawesi Tengah, CPR tahun 2019 adalah 62,93\%, turun dibandingkan tahun 2017 (65,61\%). ${ }^{7}$ Persentase peserta KB aktif berdasarkan alat kontrasepsi yang banyak digunakan adalah suntik $(63,7 \%)$, pil $(17,1 \%)$, implant $(7,4 \%)$, IUD $(7,4 \%)$, kondom $(1,2 \%)$, MOW $(2,7 \%)$ dan MOP $(0,5 \%)$ (Kementerian Kesehatan RI, 2020). Untuk Propinsi Sulawwesi Tengah, jenis kontrasepsi yang tertinggi adalah Kontrasepsi Suntik 46,3\% selanjutnya Pil 32\%, Implant 9,5\%, AKDR 7,1\%, MOW 2,9\%, kondom $1,9 \%$, dan MOP $0,3 \% .^{8}$

Menurut data BKKBN Kabupaten Poso pada tahun 2019 jumlah Pasangan Usia
Subur (PUS) sebanyak 39.339 dan akseptor KB sebanyak 38.198. Proporsi penggunaan KB IUD adalah $13,2 \%$. Pengguna IUD tertinggi berada di kecamatan Pamona Utara dengan presentasi penggunaan IUD sebanyak 32,5\% dan yang terendah berada di kecamatan Lore Selatan yaitu sebanyak $0,77 \% .{ }^{9}$ Di Kecamatan Poso Pesisir Tahun 2019 proporsi pengguna IUD hanya $3,4 \%$. Pengguna IUD di wilayah kerja puskesmas Mapane adalah 2,53\%, tertinggi ada di desa Betenia yaitu sebanyak 4,5 $\%$ dan yang terendah berada di Kelurahan Mapane yaitu sebanyak $1,63 \% .^{10}$

IUD merupakan salah satu metode kontrasepsi jangka panjang yang memiliki efektifitas sampai dengan 99,4\% dibandingkan dengan metode kontrasepsi lain seperti suntik dan pil, dengan hal itu IUD dapat mengendalikan jumlah penduduk. ${ }^{11}$ Berdasarkan hasil penelitian yang dilakukan oleh Elseria Saragih menunjukan sebanyak $37,7 \%$ memiliki pengetahuan yang baik dan $62,3 \%$ memiliki pengetahuan kurang baik. Hal ini menunjukan kurangnya pengetahuan dapat berpengaruh pada ibu untuk memilih IUD sebagai alat kontrasepsi. ${ }^{12}$ Penelitian yang dilakukan oleh Syakirah menunjukan 53,3\% mendapat dukungan dari suami dan sebanyak $46,7 \%$ yang tidak mendapat dukungan dari suami. Hal ini menunjukan dukungan suami berpengaruh dalam pengambilan keputusan terhadap pemilihan alat kontrasepsi IUD ${ }^{13}$.

Berdasarkan penelitian yang dilakukan oleh Aldriana menunjukan jumlah akseptor yang primipara sebanyak $35 \%$, multipara sebanyak $57,3 \%$ dan grande multipara sebanyak $10,9 \%$. Hal ini menunjukan mayoritas responden adalah multipara sehingga penggunaan IUD tergolong rendah. ${ }^{14}$ Penelitian lain yang dilakukan oleh Sitepu menunjukan responden mendapatkan informasi baik sebanyak 47,0\% sedangkan informasi kurang sebanyak $53,0 \%$. Hal ini menunjukan berarti ada pengaruh informasi dengan minat ibu dalam menggunakan kontrasepsi IUD. ${ }^{15}$

Menurut survei data awal yang peneliti lakukan di Desa Toini yang merupakan wilayah kerja Puskesmas Mapane, rendahnya penggunaan IUD salah satu penyebabnya adalah kurangnya pengetahuan dan pemahaman masyarakat. Masyarakat tidak mengetahui kelebihan dan kekurangan kontrasepsi IUD, masyarakat juga berfikir akan sangat sakit saat IUD dimasukkan kedalam rahim melalui vagina, sehingga menjadi takut untuk 
memasangnya. Tujuan dari penelitian ini adalah memperoleh faktor yang memengaruhi rendahnya penggunaan metode kontrasepsi IUD pada Akseptor KB.

\section{METODE PENELITIAN}

Metode penelitian ini adalah crosssectional. Penelitian ini dilaksanakan di Kelurahan Mapane. Pengumpulan data penelitian dimulai dari 19 Februari - 4 Maret tahun 2021. Populasi dalam penelitian ini adalah 336 orang akseptor KB di Kelurahan Mapane Teknik pengambilan sampel dalam penelitian ini menggunakan metode Purposive sampling. Jumlah sampel dalam penelitian ini adalah sebanyak 77 responden.

Variabel dependen dalam penelitian ini adalah pengetahuan, paritas, dukungan suami, dan informasi tenaga kesehatan. Pengetahuan baik jika skor $>76$, cukup bila 56-75 dan kurang jika $\leq 55$. Paritas terdiri dari primipara, multipara, grande multipara. Dukungan suami terdiri dari yang mendukung dan tidak mendukung. Informasi nakes terdiri dari yang mendapatkan informasi dan yang tidak mendapatkan informasi. Variabel karakteristik responden terdiri atas umur: $<20$ tahun, $20-35$ tahun, dan >35 tahun, pendidikan: SD, SMP, SMA, dan Perguruan Tinggi.

Pada kuesioner pengetahuan terdapat 20 soal pernyataan, dimana terdiri dari pernyataan positif dan negatif. Pernyataan positif yaitu apabila responden menjawab benar maka bernilai 1, apabila menjawab salah akan bernilai 0 . Pernyataan negatif, apabila responden menjawab menjawab benar maka bernilai 0 , apabila responden menjawab salah bernilai 1 . Skala pengukuran yang digunakan adalah skala Guttman. Kuesioner tentang dukungan suami terdiri dari 10 soal dengan pilihan jawaban ya atau tidak. Pertanyaan mengenai informasi petugas kesehatan terdiri dari 10 soal dengan pilihan jawaban ya atau tidak. Skala pengukuran yang digunakan adalah skala Guttman. Kuesionernya penelitian ini diadaptasi oleh penelitian Putri dan Sitepu. ${ }^{3,15}$ Kuesioner dapat dilihat pada tautan berikut https://ee.kobotoolbox.org/preview/lBQ3i2Jg

Analisis data dalam penelitian ini adalah analisis univariat dan bivariat. Data dianalisis menggunakan Stata versi 15.1. Uji hipotesis menggunakan uji chi square

\section{HASIL}

Tabel 1 menunjukan mayoritas responden berumur 20-25 tahun (66,2\%), hanya $5,2 \%$ yang menggunakan kontrasepsi IUD, $51,9 \%$ memiliki pengetahuan yang kurang tentang IUD, 49,3\% multipara, 63,6\% suami tidak mendukung ibu menggunakan IUD dan $66,8 \%$ pernah memperoleh informasi dari tenaga Kesehatan.

Tabel 1 Distribusi Karakteristik Responden terhadap Rendahnya Penggunaan Metode Kontrasepsi IUD Pada Akseptor KB di Kelurahan Mapane

\begin{tabular}{lcc}
\hline \multicolumn{1}{c}{ Karakteristik } & n & \% \\
\hline Usia (tahun) & & \\
$20-35$ & 51 & 66,2 \\
$>35$ & 26 & 33,8 \\
\hline Kontrasepsi yang digunakan & & \\
IUD & 4 & 5,2 \\
Non-IUD & 73 & 94,8 \\
\hline Pengetahuan & 6 & \\
Baik & 61 & 7,8 \\
Cukup & 40 & 40,3 \\
Kurang & & 51,9 \\
\hline Paritas & 27 & 35,1 \\
Primipara & 38 & 49,3 \\
Multipara & 12 & 15,6 \\
Grande Multipara & & \\
\hline Dukungan Suami & 28 & 36,4 \\
Mendukung & 49 & 63,6 \\
Tidak Mendukung & & \\
\hline Informasi Tenaga Kesehatan & 43 & 55,8 \\
Ya & 34 & 44,2 \\
\hline Tidak & & \\
\hline
\end{tabular}


Tabel 2 Distribusi Responden Berdasarkan Pengetahuan, Paritas, Dukungan Suami dan Informasi Nakes terhadap Rendahnya Penggunaan Metode Kontrasepsi IUD pada Akseptor KB di Kelurahan Mapane

\begin{tabular}{|c|c|c|c|c|c|c|c|}
\hline & \multicolumn{4}{|c|}{ Penggunaan Alat Kontrasepsi IUD } & \multicolumn{2}{|c|}{ Total } & \multirow[t]{3}{*}{ Nilai $\mathrm{p}$} \\
\hline & \multicolumn{2}{|c|}{ Menggunakan } & \multicolumn{2}{|c|}{ Tidak Menggunakan } & \multirow[b]{2}{*}{$\mathrm{N}$} & \multirow[b]{2}{*}{$\%$} & \\
\hline & $\mathrm{n}$ & $\%$ & $\mathrm{n}$ & $\%$ & & & \\
\hline \multicolumn{8}{|l|}{ Pengetahuan } \\
\hline Baik & 2 & 33,3 & 4 & 66,7 & 6 & 100,0 & 0,003 \\
\hline Cukup & 2 & 6,4 & 29 & 93,6 & 31 & 100,0 & \\
\hline Kurang & 0 & 0 & 40 & 100 & 40 & 100,0 & \\
\hline \multicolumn{8}{|l|}{ Paritas } \\
\hline Primipara & 0 & 0 & 27 & 100,0 & 27 & 100,0 & 0,320 \\
\hline Multipara & 3 & 7,9 & 35 & 92,1 & 38 & 100,0 & \\
\hline Grande Multipara & 1 & 8,3 & 11 & 91.7 & 12 & 100,0 & \\
\hline \multicolumn{8}{|l|}{ Dukungan Suami } \\
\hline Mendukung & 4 & 14,3 & 24 & 85,7 & 28 & 100,0 & 0,015 \\
\hline Tidak Mendukung & 0 & 0 & 49 & 100,0 & 49 & 100,0 & \\
\hline \multicolumn{8}{|l|}{ Informasi Nakes } \\
\hline $\mathrm{Ya}$ & 4 & 9,3 & 39 & 90,7 & 43 & 100,0 & 0,125 \\
\hline Tidak & 0 & 0 & 34 & 100,0 & 34 & 100,0 & \\
\hline
\end{tabular}

Tabel 2 menunjukan bahwa 100\% yang pengetahuannya kurang memilih tidak menggunakan IUD sedangkan $33,3 \%$ yang pengetahuan baik menggunakan IUD. Hasil uji statistik menggunakan chi square diperoleh nilai $\mathrm{p}=0,003$, artinya ada hubungan antara pengetahuan dengan penggunaan kontrasepsi IUD. Berdasarkan paritas, 100,0\% responden primipara tidak menggunakan IUD sedangkan hanya $8,3 \%$ ibu grande multipara yang menggunakan IUD. Hasil uji chi square diperoleh nilai $\mathrm{p}=0,320$, artinya tidak ada hubungan antara paritas dengan penggunaan IUD.

Tabel 2 menunjukan bahwa 100\% responden yang tidak mendapatkan dukungan dari suami untuk menggunakan IUD, tidak menggunakan IUD, sedangkan $14,3 \%$ yang menggunakan IUD adalah yg memperoleh dukungan dari suami. Hasil uji statistik menggunakan chi square diperoleh nilai $\mathrm{p}=0,015$, artinya ada hubungan antara dukungan suami dengan penggunaan kontrasepsi IUD. Berdasarkan informasi tentang kontrasepsi IUD dari tenaga kesehatan diperoleh $100 \%$ yang tidak pernah memperoleh informasi tidak menggunakan IUD sedangkan 9,3\% responden yang memperoleh informasi dari tenaga kesehatan menggunakan IUD. Hasil uji chi square diperoleh nilai $\mathrm{p}=0,125$, artinya tidak da hubungan informasi dengan penggunaan kontrasepsi IUD.

\section{PEMBAHASAN}

Hasil penelitian menunjukan proporsi responden yang berpengetahuan baik lebih banyak (33,3\%) untuk menggunakan IUD dibanding yang berpendidikan cukup $(6,4 \%)$. Peneliti berasumsi bahwa bahwa akseptor KB yang memiliki pengetahuan yang kurang masih banyak sehingga mereka tidak memilih IUD sebagai alat kontrasepsi. Penelitian di Brasil menemukan bahwa sebagian besar wanita memiliki tingkat pengetahuan di atas median, sepertiganya tertarik untuk menggunakan IUD. ${ }^{16}$ Hasil penelitian lain mengatakan bahwa akseptor KB yang berpengetahuan kurang baik dapat mempengaruhi mereka untuk tidak menggunakan IUD. Hal ini terlihat dari hasil penelitian yang menunjukkan bahwa mayoritas akseptor $\mathrm{KB}$ berpengetahuan kurang dan sebagian besar tidak menggunakan IUD. ${ }^{12}$ Adanya pengaruh tingkat pengetahuan terhadap pemakaian IUD dikaitkan beberapa faktor seperti pengalaman pribadi, motivasi suami atau orang terdekat, sosial dan budaya setempat, persepsi, pendidikan serta usia ikut mempengaruhi responden untuk menggunakan atau tidak menggunakan IUD. ${ }^{17}$ Olehnya itu, kegiatan seperti penyuluhan dapat dilakukan untuk meningkatkan pengetahuan tentang IUD. ${ }^{18}$

Temuan penelitian yang berkaitan dengan paritas yakni lebih banyak yang menggunakan IUD adalah grande multipara. Walaupun secara statistik tidak berhubungan, 
namun jika dilihat beda proporsinya maka dapat dikatakan bahwa paritas dapat menjadi faktor penentu pemilihan MKJP seperti IUD. Kami berasumsi bahwa pada primipara tidak ada yang menggunakan IUD dikarenakan mereka masih ingin memiliki anak dalam jangka waktu dekat sehingga lebih memilih menggunakan metode kontrasepsi lain seperti PIl atau suntik. Pada multipara dan grandemultipara yang tidak menggunakan IUD dapat disebabkan karena kurangnya pengetahuan dan ingin menambah anak karena alasan jenis kelamin anak. Bagi wanita yang mempunyai anak perempuan ingin mempunyai anak laki-laki dan sebaliknya. Studi terdahulu menyebutkan bahwa tingginya paritas wanita pada periode postpartum sangat terkait dengan menggunakan MKJP. Semakin bertambahnya jumlah anak-anak meningkatkan kemungkinan untuk menggunakan MKJP juga meningkat. beberapa hal yang mendasarinya adalah paritas dapat secara tidak langsung mewakili akumulasi pengetahuan kontrasepsi melalui paparan ganda terhadap pendidikan dan/atau konseling kontrasepsi melalui setiap siklus kehamilan. Selain itu, wanita multipara ini mungkin sangat termotivasi untuk menggunakan MKJP karena mereka lebih mungkin untuk mencapai ukuran keluarga yang mereka inginkan. ${ }^{19}$ Karena efektifitas IUD yang tinggi dalam mencegah konsepsi, beberapa studi justru merekomendasikan penggunaan IUD pada ibu muda, bahkan nulipara. ${ }^{20,21}$ Penelitian yang dilakukan oleh Handayani menyatakan bahwa kebanyakan ibu memakai IUD saat anak kedua dan ketiga. banyaknya anak hidup mempengaruhi PUS dalam menentukan metode kontrasepsi yang akan digunakan. $^{22}$ PUS yang jumlah anak lebih banyak, peluang untuk memakai alat kontrasepsi yang efektif seperti IUD lebih besar dibandingkan pasangan yang mempunyai jumlah anak lebih sedikit. ${ }^{23}$

Dalam budaya patriarki, keputusan suami adalah hal mutlak, olehnya itu banyak hal yang berkaitan dengan kesehatan perlu dukungan dari suami, termasuk dalam hal pemilihan kontrasepsi. Hasil penelitian kami menunjukan $14,3 \%$ yang menggunakan IUD memperoleh dukungan dari suami, sedangkan yang tidak memperoleh dukungan tidak ada satupun yang menggunakan IUD. Dukungan suami mempengaruhi penggunaan IUD. Komunikasi antara suami dan istri memegang peranan penting dalam penggunaan alat kontrasepsi dimana mereka harus berdialog tentang kontrasepsi yang akan digunakan. ${ }^{24}$ Proses pemilihan IUD dapat tidak lepas dari dukungan pasangan karena umumnya suami adalah keputusan utama pembuat dalam keluarga. Dukungan pasangan akan mempengaruhi minat wanita dalam menggunakan IUD. ${ }^{24-26}$ Dukungan suami juga merupakan salah satu faktor sosial yang mempengaruhi penggunaan alat kontrasepsi. Itu berdampak positif penggunaan IUD oleh istri yang menjadi lebih percaya diri dan dengan demikian tidak lagi ragu untuk menggunakan IUD. ${ }^{26-28}$

Dukungan informasi tenaga kesehatan terkait kontrasepsi juga merupakan hal penting. Walaupun hasil penelitian secara statistik tidak ada hubungan antara informasi tenaga kesehatan dengan penggunaan kontrasepsi IUD, namun terdapat $9,3 \%$ ibu yang menggunakan IUD pernah memperoleh informasi dari tenaga kesehatan dibandingkan yang tidak pernah. Secara keseluruhan, hanya lebih setengah $(55,8 \%)$ dari responden yang mendapatkan informasi tentang kontrasepsi IUD dari tenaga kesehatan. Hal ini tentu masih rendah. Dukungan informasi petugas kesehatan merupakan faktor yang ikut mendukung peran serta ibu dalam keikutsertaan menggunakan IUD.

Hasil penelitian Mahmudah \& Indrawati menyatakan bahwa ada hubungan antara informasi tenaga kesehatan dalam memberikan konseling $\mathrm{KB}$ dengan penggunaan alat kontrasepsi pada wanita pasangan usia subur. konseling dengan metode yang tepat sangat mempengaruhi keputusan ibu dalam menggunakan alat kontrasepsi jangka panjang seperti IUD. ${ }^{28}$ Selain itu kurangnya sosialisasi dari petugas kesehatan yang menyebabkan ibu enggan menggunakan IUD, serta keterampilan dari petugas kesehatan dalam mempengaruhi ibu untuk menggunakan kontrasepsi harus terus ditingkatkan. 29,30

Implikasi dari penelitian ini adalah menjadi informasi tambahan bagi tenaga kesehatan di puskesmas maupun penyuluh lapangan $\mathrm{KB}$ agar berinovasi dalam memberikan informasi terkait kontrasepsi khususnya IUD sebagai MKJP dengan efektifiktas tinggi dan pendekatan yang lebih baik kepada pasangan calon akseptor KB sehingga informasi yang disampaikan dapat diterima dengan baik oleh calon akseptor dan pasangannya. Tidak keterbatasan dalam penelitian yang kami lakukan ini. 


\section{KESIMPULAN DAN SARAN}

Dari hasil penelitian dapat disimpulkan bahwa pengetahuan yang kurang dan tidak adanya dukungan suami adalah faktor yang mempengaruhi rendahnya penggunaan kontrasepsi IUD. Penelitian ini menyarankan kepada petugas kesehatan puskesmas untuk meningkatkan pemberian penyuluhan baik secara personal maupun kelompok terkait kontrasepsi IUD dan melibatkan suami dalam pemberian penyuluhan sehingga dapat menambah pengetahuan ibu dan suami. Selain itu, diharapkan kepada bidan lebih pro aktif lagi dalam memberikan edukasi terkait KB IUD, walaupun ibu datang dengan kontrasepsi pilihannya bidan harus tetap memberikan konseling terkait $\mathrm{KB}$.

\section{DAFTAR PUSTAKA}

1. Agustina L. Faktor-Faktor yang Mempengaruhi Rendahnya Minat Akseptor KK untuk Menggunakan KB IUD di Dusun Sayang Desa Mokong Kecamatankecamatan Moyo Hulu. Jurnal Kesehatan dan Sains. 2020;3(2):10-3.

2. Badan Pusat Statistik. Hasil Sensus Penduduk 2020. Berita Resmi Statistik. 2021.

3. Putri RP, Oktaria D. Efektivitas Intra Uterine Devices (IUD) Sebagai Alat Kontrasepsi. Majority. 2016;5(4):138-41.

4. Kantorová V, Wheldon MC, Ueffing $\mathrm{P}$, Dasgupta ANZ. Estimating progress towards meeting women's contraceptive needs in 185 countries: A Bayesian hierarchical modelling study. Drake AL, editor. PLOS Medicine. 2020 Feb 18;17(2):e1003026.

5. United Nations. Family Planning and the 2030 Agenda for Sustainable Development: Data Booklet. (ST/ESA/ SER.A/429). Department of Economic and Social Affairs, Population Division. 2019.

6. United Nations. Contraceptive Use by Method 2019. Geneva, Switzerland: UN; 2019.

7. Badan Pusat Statistik. Angka Pemakaian Kontrasepsi (CPR) Semua Cara Pada Pasangan Usia Subur Usia 15-49 Tahun Yang Pernah Kawin (40\% Bawah), Menurut Provinsi [Internet]. bps.go.id2. 2020. Available from: https://www.bps.go.id/indikator/indikator/vie w_data/0000/data/1550/sdgs_1/1

8. Dinas Kesehatan Sulawesi Tengah. Profil Kesehatan Provinsi Sulawesi Tengah Tahun 2019. Palu: Dinas Kesehatan Sulawesi Tengah; 2020. 1-222 p.

9. BKKBN Kab Poso. Cakupan Penggunaan
Kontrasepsi Kab Poso 2019. Poso; 2020.

10. Puskesmas Mapane. Cakupan Penggunaan Kontrasepsi Puskesmas Mapane 2019. Mapane; 2020.

11. Birliani WS, Dwi Ernawati. Gambaran Faktor - Faktor yang Mempengaruhi Pemilihan Alat Kontrasepsi IUD di Puskesma Jetis Kota Yogyakarta. In: DSpace Unisa Yogyakarta. Yogyakarta; 2018. p. 12.

12. Saragih E. Faktor-Faktor Yang Mempengaruhi Keikutsertaan Ibu Menjadi Akseptor Alat Kontrasepsi Dalam Rahim ( AKDR ) Di Desa Bonandolok Kecamatan Sijamapolang Tahun 2019. Journal Of Midwifery Senior. 2019;2:36-42.

13. Rasyid SN, Panai R, Usman S. Faktor-Faktor yang Mempengaruhi Pemilihan Metode Alat Kontrasepsi Dalam Rahim pada Akseptor Kb di Puskesmas Bonepantai. In: Akademika Jurnal Ilmiah Media Publikasi Ilmu Pengetahuan dan Teknolog. Gorontalo; 2019. p. 26.

14. Aldriana N. Gambaran Faktor-Faktor yang Mempengaruhi Rendahnya Pemakaian KB AKDR di Puskesmas Rambah Samo. Jurnal Mitra Kencana Keperawatan dan Kebidanan. 2013;1(2):8.

15. Sitepu R. Faktor Yang Mempengaruhi Minat Ibu Menggunakan KB Intra Uterine Device (IUD) di Puskesmas Binjai Estate Tahun 2019. Helvetia Repositori. Istitut Kesehatan Helvetia; 2019.

16. Borges ALV, Araújo KS, Santos OA dos, Gonçalves RFS, Fujimori E, Divino E do A. Knowledge about the intrauterine device and interest in using it among women users of primary care services. Revista LatinoAmericana de Enfermagem. 2020;28:e3232.

17. Andria R. Faktor-Faktor yang Mempengaruhi Rendahnya Penggunaan Alat Kontrasepsi IUD pada Akseptor KB di Desa Pulo Ara Kecamatan Kota Juang Kabupaten Bireuen. Jurnal Kesehatan Almuslim. 2017;2(September):1-3.

18. Zulfitriani Z, Nurfatimah N, Entoh C, Longgupa LW, Ramadhan K. Penyuluhan Guna Meningkatkan Pengetahuan Wanita Usia Subur (WUS) tentang KB IUD. Community Empowerment. 2021;6(3):374-9.

19. Anguzu R, Sempeera H, Sekandi JN. High parity predicts use of long-acting reversible contraceptives in the extended postpartum period among women in rural Uganda. Contraception and Reproductive Medicine. 2018 Dec 9;3(1):6.

20. Madden T, McNicholas C, Zhao Q, Secura GM, Eisenberg DL, Peipert JF. Association of Age and Parity With Intrauterine Device Expulsion. Obstetrics \& Gynecology. 2014 Oct;124(4):718-26. 
21. Aoun J, Dines VA, Stovall DW, Mete M, Nelson CB, Gomez-Lobo V. Effects of Age, Parity, and Device Type on Complications and Discontinuation of Intrauterine Devices. Obstetrics \& Gynecology. 2014 Mar;123(3):585-92.

22. Handayani D. Faktor-faktor yang Mempengaruhi Ibu dalam Pengambilan Keputusan Memilih Alat Kontrasepsi Dalam Rahim (AKDR) di Wilayah Bidan Praktik Swasta Titik Sri Suparti Boyolali. Jurnal Kesmadaska. 2010;1(1):56-65.

23. Etnis BR, Hastono SP, Widodo S. FaktorFaktor yang Berhubungan dengan Penggunaan Kontrasepsi IUD pada Wanita Usia Subur (WUS) di Desa Tanjungtani Kecamatan Prambon Kabupaten Nganjuk 2016. Global Health Science. 2018;3(1):10314.

24. Setyorini RH, Revika E, Utami RW, Oktriyanto O, P MD. Husband's support on the use of Intra Uterine Device (IUD) and implant contraceptives among Indonesian couples. Journal of Health Technology Assessment in Midwifery. 2020;3(2):87-93.

25. Mariati T. Dukungan Suami Dengan Pemilihan Pengunaan Kontrasepsi Intra Uterine Device (IUD). Jurnal Manajemen Kesehatan Yayasan RSDr Soetomo. 2018 Nov 8;4(2):98.

26. Nuraini DA, Muhlis ANA. The Correlation Between Husband Support and The Use Of Intra-Uterine Device (IUD) in Women of Childbearing Age: A Meta-Analysis Study. Jurnal Biometrika dan Kependudukan. 2021 Jun 25;10(1):68.

27. Harahap YW, Hairani N, Dewi SSS. Hubungan dukungan suami dan umur akseptor $\mathrm{kb}$ dengan pemakaian metode kontrasepsi IUD. Jurnal Kesehatan Ilmiah Indonesia. 2019;4(2):29-36.

28. Mahmudah LTN, Indrawati F. Analisis Faktor yang Berhubungan Dengan Pemilihan Metode Kontrasepsi Jangka Panjang (Mkjp) pada Akseptor Kb Wanita di Kecamatan Banyubiru Kabupaten Semarang. Unnes Journal of Public Health. 2015;4(3):76-85.

29. Chakraborty NM, Murphy C, Paudel M, Sharma S. Knowledge and perceptions of the intrauterine device among family planning providers in Nepal: a cross-sectional analysis by cadre and sector. BMC Health Services Research. 2015 Dec 28;15(1):39.

30. Hohmann HL, Cremer ML, Gonzalez E, Maza M. Knowledge and attitudes about intrauterine devices among women's health care providers in El Salvador Heather. Scielo Public Health. 2011;29(2):198-202. 